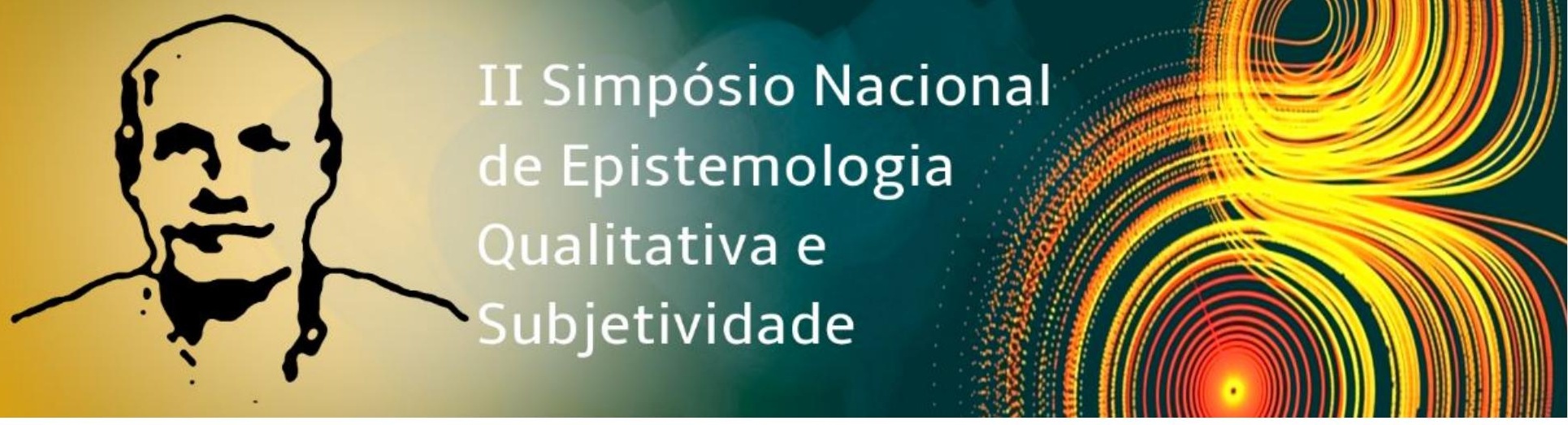

- Eixo temático: 11. Subjetividade e saúde humana

\title{
Sistema prisional, saúde mental e subjetividade: um estudo de caso
}

Indiara Galvão Oliveira Rubim ${ }^{1}$, UniCEUB, indi.galvao@gmail.com Daniel Magalhães Goulart ${ }^{2}$, UniCEUB, danielgoulartbr@gmail.com

\section{Resumo}

Esta apresentação fundamenta-se em uma pesquisa, cujo objetivo foi compreender a configuração subjetiva da experiência no cárcere e seus desdobramentos na saúde mental de um ex-presidiário. A pesquisa fundamentou-se na Teoria da Subjetividade a partir de uma perspectiva histórico-cultural desenvolvida por González Rey (2002,2005, 2015, 2017). Apesar da existência de leis que visam ao cuidado da saúde dos presidiários - como a Lei de Execução Penal (LEP - No 7.710/84) -, nota-se que tais cuidados ainda são oferecidos de forma precária. Num primeiro momento, discute-se o sofrimento psíquico na vivência do processo de exclusão social (relacionada ao afastamento da família, do trabalho e dos espaços educacionais), de convivência com a violência e de inclusão no sistema carcerário. Num segundo momento, é proposta a articulação entre os conceitos da Teoria da Subjetividade e o tema em questão. Posteriormente, evidencia-se a construção de informação do caso Alexandre, que tem 32 anos, é solteiro, pai de dois filhos, servente de obras e residente em uma cidade de Brasília. Ele passou por diversos presídios de Brasília entre 2005 e 2017, totalizando 12 anos de reclusão. Para a pesquisa, foi utilizado o método construtivo-interpretativo, que se baseia na Epistemologia Qualitativa. Essa perspectiva tem como premissa que o conhecimento é uma construção interpretativa sobre a realidade, não sua apropriação linear. Durante a pesquisa de campo, foram usados os seguintes instrumentos: dinâmica conversacional, complemento de frases, diálogos sobre desenhos e redação sobre documentário. Os indicadores e hipóteses construídos 


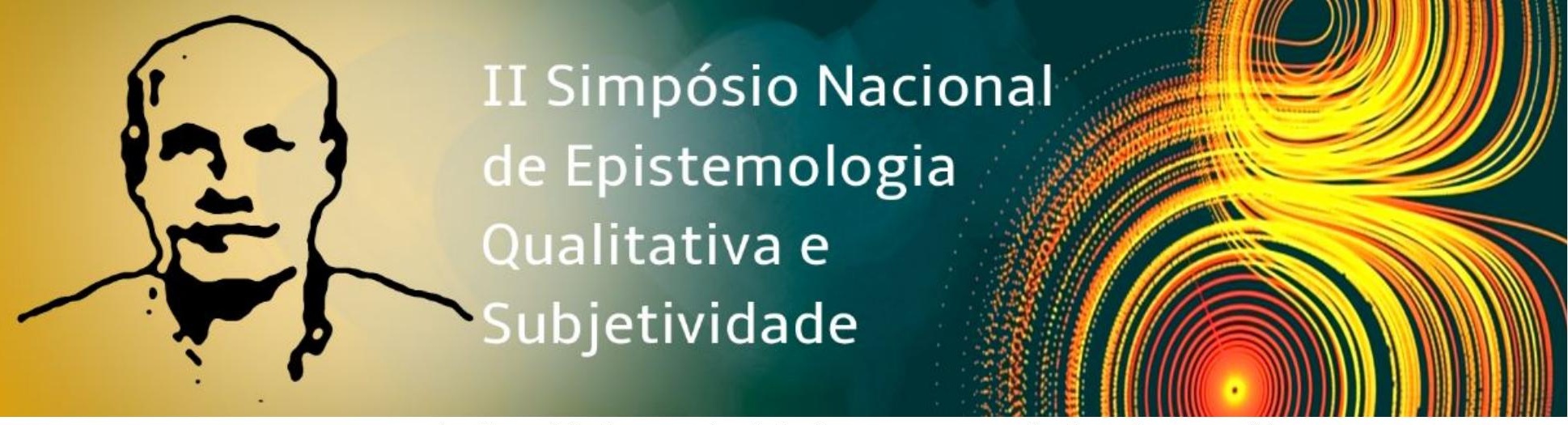

apontaram para uma produção subjetiva a princípio intensamente relacionada ao sofrimento, mas que posteriormente foi se transformando com a geração de recursos subjetivos orientados ao desenvolvimento subjetivo. Constataram-se as dificuldades existentes no cuidado dentro do cárcere, o que demandou elaborações teóricas e técnicas quanto à saúde mental dentro e fora dos presídios. Para a discussão fundamentada neste trabalho, questiona-se: como a psicologia e outras áreas do conhecimento podem colaborar para promover a saúde mental em situações de cárcere?

Palavras-chave: Sistema prisional, Subjetividade e Saúde mental.

\section{Referências bibliográficas}

BRASIL. Ministério da SaúdePortaria Portaria n⿳ 7.210, de 11 de julho de 1984. Do Objeto e da Aplicação da Lei de Execução Penal. Disponível em: $<$ http://www.planalto.gov.br/ccivil_03/leis/L7210.htm>. Acesso em: 16 de nov 2018.

MARTÍNEZ, Albertina Mitjáns; REY, Fernando Luis González. Subjetividade: teoria, epistemologia e método. Campinas: Alínea, 2017.

REY, Fernando Luis González. Pesquisa qualitativa em psicologia: caminhos e desafios. Tradução de Marcel A. F. Silva. São Paulo: Pioneira Thomson Learning, 2002.

. Pesquisa qualitativa e subjetividade: os processos de construção da informação.

2. ed. Tradução de Marcel Aristides Ferrada Silva. São Paulo: Cengage Learning, 2005.

A saúde nas tramas complexas da cultura, das instituições e da subjetividade. In: GONZÁLEZ REY, F.; BIZERRIL, J. (Orgs.). Saúde, cultura e subjetividade: uma referência interdisciplinar. Brasília: UniCEUB, p. 9-33, 2015. 